4. Українсько-латвійські музичні зв'язки як вияв інтеграційних процесів у європейському культурному просторі. VII Міжнародний конгрес українців. Збірник наукових статей. Мистецтвознавство. Культурологія \Г. Скрипник; НАНУ; ІМФЕ ім. М. Т. Рильського. Київ. 2008. $320 \mathrm{c}$.

DOI https://doi.org/10.30525/978-9934-26-004-9-36

\title{
ТРАДИЦЙНЕ ВЕСІЛЛЯ УКРАЇНЦІВ ЯК ЕТНОКУЛЬТУРНИЙ ФЕНОМЕН УКЛАДАННЯ «МИРУ» МІЖ «ЧУЖИМИ» СВІТАМИ
}

\author{
Щербіна I. B. \\ кандидат мистеитвознавства, доцент, \\ дочент кафедри музикознавства та вокально-хорового мистецтвва \\ Уманського державного педагогічного університету \\ імені Павла Тичини \\ м. Умань, Черкаська область, Украӥна
}

Традиційна соціально-юридична та релігійно-магічна система людського соціуму формувалася в умовах боротьби особи за існування як біологічної і водночас соціальної істоти - табу забезпечували порядок у громаді, а обрядові дії підтримували рівновагу між «чужими» світами засобом виконання ритуалів, головна функція яких - укласти максимально вигідний для обох сторін договір і тим самим уникнути ворожнечі між «чужими» світами та унеможливить проникнення хаосу в «свій» світ. Досягти успіху в цій справі можливо лише за умов компетентного укладання угоди, яка враховує можливості, потреби і закони як «свого» світу, так і «чужого» оскільки саме сув'язь ворожнечі й любові, за визначенням О. Потебні, створюють неосяжний світ взаємозв'язку причин та наслідків, а «одруження є не що інше, як символ боротьби життя й смерті. Саме весільне застілля є символом боротьби, де п'яна людина вважається мертвою, а весілля в цілому - миром» [1, с. 11-12].

Досліджуючи весільну обрядовість слов'ян, М. Сумцов дійшов висновку, що всі народні гуляння первинно були складовими язичницького свята «Веселія», присвяченого служінню богу Сонця Дажбогу, яке врівноважувало світовий порядок: у ньому брали активну участь боги та люди, які намагалися вплинути на космологічні явища $\mathrm{i}$ тим самим одержати багатий врожай і забезпечити власний добробут. 
Воно було сповнене ритуалами, які з часом відокремилися за своїм функціональним призначенням у відповідні обрядові комплекси. Весільна обрядовість слов'янських народів, зокрема, українського, бере свої джерела і назву від цього свята [2, с. 3-5] - вона увібрала в себе весь звичаєво-правовий ритуально-магічний комплекс, оскільки життя майбутнього подружжя передбачає залучення всіх сфер господарської і позавиробничої діяльності.

За своєю структурою український традиційне весілля є системою циклів обрядових дій, пов'язаних $з$ дійовими особами (весільні чини) i предметами (символи, атрибути) в якій ритуал є методом спілкування між двома і більш сторонами та укладання договору між представниками «чужих» світів, який реалізується у трьох напрямках інтерпретації протиставлення: соціальному (чоловіче-жіноче, старе-молоде, посвячений-непосвячений...); етнічному (людина-не людина, живанежива людина, предок свій-чужий...); сакральному (де чужий-свій відзначається, як людське своє, нелюдське-чуже).

Кожна дійова особа у традиційній український весільній обрядовості на рівні соціуму належить до «свого» і одночасно «чужого» світу. Молода в межах свого роду: є «своя» до жіночої статі (свахи матері і тітки молодшого роду; дружки та боярки - сестри та подруги молодої) i «чужа» до чоловічої (старости - брати свах та батьки й дядьки молодшого роду, брати молодої та їхні друзі); є «своєю» до соціальної групи дівчат та парубків і «чужа» до соціальної групи заміжніх жінок (коровайниць, свах) та одружених чоловіків (старости, підстарости, свати), одночасно залишаючись «своєю» для свого роду і «чужою» для роду молодого, в межах якого відбувається аналогічне протиставлення «свій-чужий». Весільні чини, які належать до роду молодої - відносно цього роду $\epsilon$ представниками «свого» світу, і якщо не пов'язані кровними зв'язками в дійсному житті - під час весілля, вважаються родичами. Для роду молодого - вони представники «чужого» світу. Те ж саме стосується і весільних чинів, які належать до роду молодого - два старости (одного з них називають дружбою - дядька молодого), старший боярин і бояри (брати і друзі молодого), світилки (сестри молодого та їхні подруги), свахи (одружені жінки - родички і сусідки молодого) [3, с. 104]. Свати - представники «свого» світу відносно одного роду i «чужі» по відношенню до іншого роду. Вони виконують функції посередників між «чужими» двома родами на рівні соціуму [3, с. 104] вирішуючи соціально-організаційні та економічні питання.

Функцію посередника між «своїм» та «чужим» світом на сакральному рівні первинно виконували чаклуни або волхв, пізніше у XIX-XX ст. 
знавець ритуалу або хтось 3 весільних чинів, зокрема, мати, сваха, дружка тощо [2, с. 8-9] семантично вирішуючи питання укладання «миру» між «чужими» світами.

На сакральному рівні всі весільні чини є представниками «свого» світу, а предмети - «сакралізованними речами» які використовуються як: знаряддя охорони від негативного впливу «чужого» світу; символи Богів - покровителів шлюбу, атрибути та предмети жертвоприношення та обміну [3, с. 104.]. До «чужого» світу відносяться трансцендентальні потойбічні сили: «світ Богів», який, відповідно семантики виконаного ритуалу впорядковує всесвіт і бере під своє заступництво людину (яка не порушує космічних законів) наділяючи ії добробутом і щасливою долею; «світ» істот нижчого рівня, який свої дії спрямовує на наведення хаосу i, за умовами принесеного жертвоприношення, може тимчасово допомагати особі, вимагаючи за свої послуги «людської власно-життєвої розплати»; «світ предків», який складається з душ померлих і частково $є$ «своїм» світом для того чи іншого роду, оскільки у минулому належали до світу людини. Укладаючи договір із світом «предків» людина сподівалася як отримати від пращурів підтримку, так i уникнути негативних наслідків від їх діяльності щодо навмисного порушення космічних законів із метою наведення шкоди своїм же нащадкам. Тому перед весіллям молода обов'язково йшла на кладовище відвідати родичів, а дівчині-сироті співали особливих сирітських пісень [3, с. 104]. Під час виконання ритуалів, пов'язаних 3 ініціацією молодої (посад, покривання...), дівчина для свого роду символічно вмирає, а для роду, в який вона переходить, народжується як жінка і приймається «своєю» як продовжувач роду. Молода після умовної смерті (до молодого це відноситься, якщо він йде у прийми) набуває своєрідної інновації і вважається «своєю» в «чужому» світі молодого та «чужою» в «своєму» світі батьків одночасно залишаючись «своя» в «своєму» світі батьків, який вже не є іiі світом і «чужа» в «чужому» світі молодого, який уже є її світом. Молодий по відношенню до «свого» світу залишається своїм i набуває статусу «свого» в світі родини батьків молодої, одночасно залишаючись в ньому «чужим» (якщо молодий іде у прийми, це стосується його молодиці).

Комплекс весільних ритуальних дій стверджував укладання «миру» між «чужими» на соціальному і сакральному рівнях, а саме - єднання двох родів (коровайні обряди) результатом якого $є$ народження нової сім’і (посад...) і санкціонування нового соціальний статус молодят (шлюбна ніч, перезва, рядженні...): чоловік і дружина становляться «чужим» світом для покоління неодружених і «своїм» по відношенню до 
групи сімейних людей. Після весілля, як окремий світ молодого подружжя для двох родів та їх батьків є одночасно «своїми» $\mathrm{i}$ «чужими» на різних рівнях співвідношення «чуже-своє» [12, с. 107].

Українське весілля як етнокультурний феномен духовної та ментальної практики людини щодо програмування майбутнього щасливого подружнього життя та юридичного санкціонування шлюбу в модусі регулювання суспільно-економічних і статевих взаємовідносин між «чужими» i «своїми» людьми в громаді і за їі межами - нині функціонує у рудименто-скороченій пасивно-побутовій формі існування визначаючи права та обов'язки між чоловіком і жінкою, їх ставлення як одне до одного, так і до дітей та батьків.

\section{Література:}

1. Потебня А. А. О некоторых символах в славянской народной поэзии. О связи некоторых представлений в языке. О купальских огнях и сродных с ними представлениях. О доле и сродных с нею существах. Харьков: Из. М. В. Потебня. Тип. «Мирный труд», 1914. 243 с.

2. Сумцов Н.Ф. Религиозно-мифическое значение малорусской свадьбы. (Изд. редакции «Киевской старины»). К.: Тип. Г. Т. КорчакНовицкого, 1885. $20 \mathrm{c}$.

3. Щербіна I. В. Сутність традиційного весільного обряду на Україні. Культура України: зб. статей: Вип. 4. Харків: ХДАК, 1997. С. 101-110. 